\title{
Evaluation of the Quality of Household Waste Leachate Treated by Settling Ponds at the Ouagadougou Waste Treatment and Valorization Center
}

\author{
Vianney Demakoye1, Koné Martine ${ }^{2 *}$, Ouattara Yacouba², Guinko Seydou², Sawadogo Siméon ${ }^{3}$ \\ ${ }^{1}$ Ecole Supérieure Polytechnique Privée de la Jeunesse, Ouagadougou, Burkina Faso \\ ${ }^{2}$ Centre National de la Recherche Scientifique et Technologique, Ouagadougou, Burkina Faso \\ ${ }^{3}$ Direction de la Propreté de la Commune de Ouagadougou, Ouagadougou, Burkina Faso \\ Email: *koneba2003@yahoo.fr
}

How to cite this paper: Demakoye, V., Martine, K., Yacouba, O., Seydou, G. and Siméon, S. (2017) Evaluation of the Quality of Household Waste Leachate Treated by Settling Ponds at the Ouagadougou Waste Treatment and Valorization Center. Journal of Environmental Protection, 8, 1567-1582. https://doi.org/10.4236/jep.2017.812096

Received: October 13, 2017

Accepted: November 26, 2017

Published: November 29, 2017

Copyright $\odot 2017$ by authors and Scientific Research Publishing Inc. This work is licensed under the Creative Commons Attribution International License (CC BY 4.0).

http://creativecommons.org/licenses/by/4.0/

\begin{abstract}
In African cities, today's patterns of consumption are increasingly generating solid and liquid waste. This waste requires adequate management as it poses significant risks to public health and the environment. To meet the challenge in Ouagadougou, a waste treatment and recycling center has been implemented. The leachates from household refuse evacuated in this center are treated by two series settling ponds whose performances have been evaluated throughout the present study. For this purpose, samples were taken from the basins and analyzed weekly for two months. On these samples, the physical parameters $(\mathrm{pH}$, temperature, conductivity), organic pollution indicators $\left(\mathrm{BOD}_{5}, \mathrm{COD}, \mathrm{SS}\right)$, nitrogen pollution (nitrate, nitrite) and phosphorus pollution (ortho-phosphates) were evaluated according to AFNOR standards. The average of suspended-matter contents above $13,000 \mathrm{mg} / \mathrm{L}$ and this particulate pollution abatement recorded is $2.04 \%$, whereas the Chemical Oxygen Demand reached respective maximum values of 660 and $480 \mathrm{mg} / \mathrm{L}$ for both basins. Nutrients such as nitrates were well eliminated whereas orthophosphates are released. $\mathrm{PH}$ values varied between 8.62 and 9.51, while electrical conductivity values varied between 482 and $625 \mu \mathrm{S} / \mathrm{cm}$. The Fecal Coliforms reached maximum concentrations of 10,000 and $12,800 \mathrm{UFC} / 100 \mathrm{~mL}$.
\end{abstract}

\section{Keywords}

Waste, Leachate, $\mathrm{BOD}_{5}$, Fecal Coliforms, Conductivity, $\mathrm{COD}, \mathrm{NO}_{3}$

\section{Introduction}

In the context of sustainable development, African towns are confronted with 
wastes management in general and particularly those of solid waste [1]. By 2020, more than one in two African will live in the city [2]. The city of Ouagadougou experienced a strong urbanization of 85\% from 1996 to 2006, and this resulted in the increase of waste generated by activities. The capital city of Burkina Faso produces 300,000 tons of solid waste each year [2]. This country is facing with major challenges to be taken up as far as the environment preservation and the way of life improvement are concerned, looking at the lack of suitable infrastructures to ensure the management of waste water and solid waste.

For this purpose, in 2004 the city of Ouagadougou has drawn up a master plan to manage solid waste. This consisted in creation of pré-collection centers and a technical Burying Center which opened its doors in April 2005.

This Center was renamed Waste Treatment and Valorization Center (WTVC) in 2007 where income-generating activities have emerged such as the recycling of plastic into utility objects or the composting of organic waste and a leachate treatment component [2]. This study aims at estimating the purification performance of the treatment basins of leachate derived from household rubbish evacuated in this Center.

\subsection{Main Objective}

This study aims at evaluating the treatment efficiency of leachate derived from household refuse through a device of two aerobic basins in series.

\subsection{Specific Objectives}

To establish the typology of leachate produced in the Waste Treatment and Valorization Center to evaluate the purification performance in $\mathrm{BOD}_{5}, \mathrm{COD}$, and mineral elements such as nitrogen and phosphorus.

\section{Material and Methods}

\subsection{Household Leachate Treatment Technologies}

Leachate from urban dump is one of the major constraints for the management of refuse dump. Their composition varies from one discharge to another depending on the nature and age of the waste. It evolves according to the state of degradation of the waste. The different types of leachate due to their variable composition must undergo specific treatments before they are discharged into the receiving environment. We therefore distinguish:

Biological processes: these are the oldest processes used for the treatment of leachates, because of their efficiency to reduce polluting loads in organic matter. Biodegradation is provided by microorganisms (bacteria) in aerobic or anaerobic environments. Biological processes such as activated sludge or lagoon used in the case of this study.

Physico-chemical processes: they are based on coagulation-flocculation, adsorption and precipitation. These processes are used as pre-treatment or finishing step to complete the treatment process, or to eliminate specific pollutants. 
This process makes it possible to eliminate the colloidal organic matter.

Thermal processes: these are old processes based on the evapo-concentration that is commonly used for the treatment of leachates and the recovery of waste in biogas.

Membrane processes: This is a combination of processes such as microfiltration, ultrafiltration or nanofiltration. The latter make it possible to pretreat the leachate before a reverse osmosis finishing treatment and making it possible to obtain an effluent whose quality meets the rejection standards.

\subsection{Presentation of the Waste Treatment and Valorization Center (WTVC)}

The Waste Treatment and Valorization Center is located at about ten kilometers in the Northern part of Ouagadougou in Burkina Faso. It lies on a surface of seventy (70) hectares, divided into four (4) phases with well-defined surfaces: 1st phase ( 25 hectares), 2 nd phase ( 15 hectares), 3rd phase ( 15 hectares) for a lifespan of twenty (20) years and a capacity of 6.1 million cubic meters (Figure 1).

The WTVC mainly plays two (02) roles:

Burying solid waste (household rubbish, special industrial and biomedical waste).

Valorizing solid waste (composting and valorizing plastic).

The Center includes:

A weighing premise equipped with a bascule bridge;

Six cells receiving the household rubbish (HR);

Four cells receiving industrial and special waste (ISW);

Two basins for treatment of the leachate deriving from industrial and special waste;

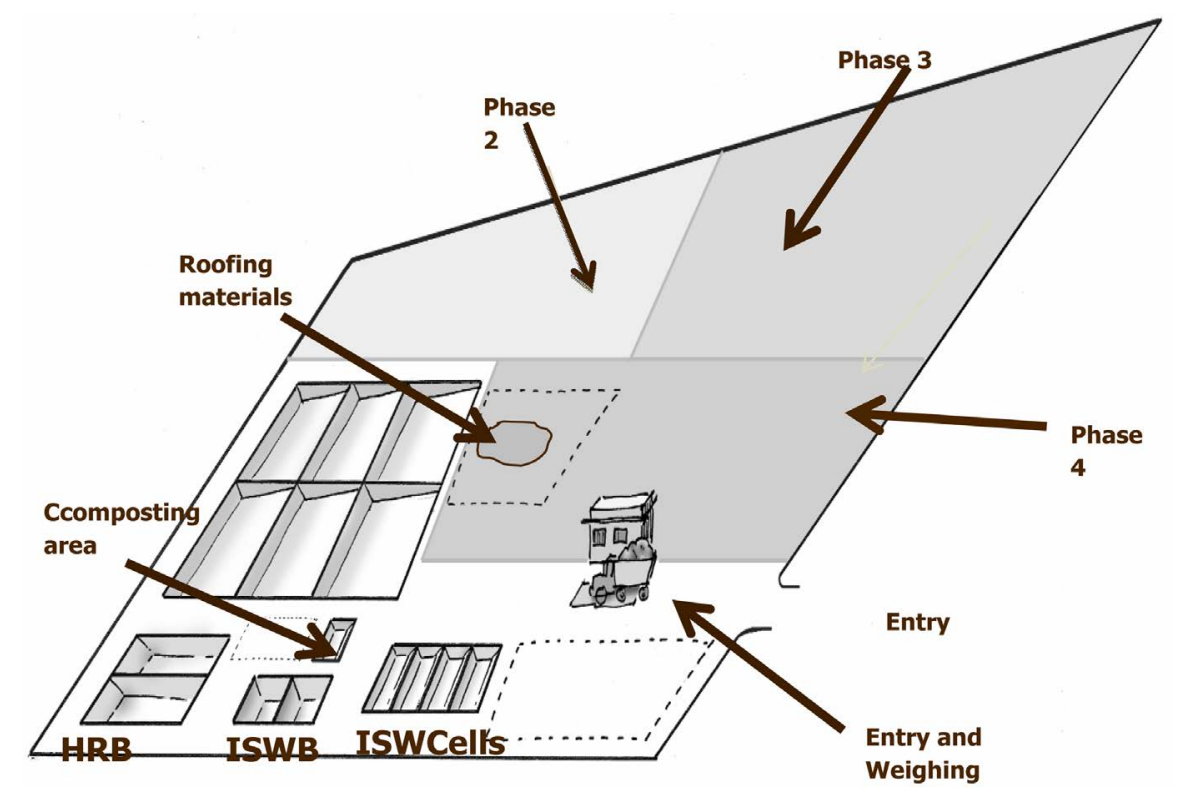

Figure 1. Diagram of organization of the waste treatment and valorization center (Source: Direction de la Propreté). 
One composting and maturing unit;

One valorization unit of plastic waste;

Three wells for observing the quality of ground water;

Two observation wells of biogas underground migration.

This work concerns the treatment basins (Figure 2 and Figure 3 ) of the household rubbish leachate which characteristics are written down in Table 1. It can be noticed that the basins are oversized. This is done in anticipation of an increase in the waste capacity of the center. Due to oversizing, the nominal residence time of 44 days remains lower than the actual residence time of the water in the basins.

\subsection{Material}

The sampling material is composed of plastic, small bottles with one-liter capacity containing the samples meant for physico-chemical analyses and $250 \mathrm{ml}$ glass sterilized vials for bacteriological analyses. Each sampling small bottle has the

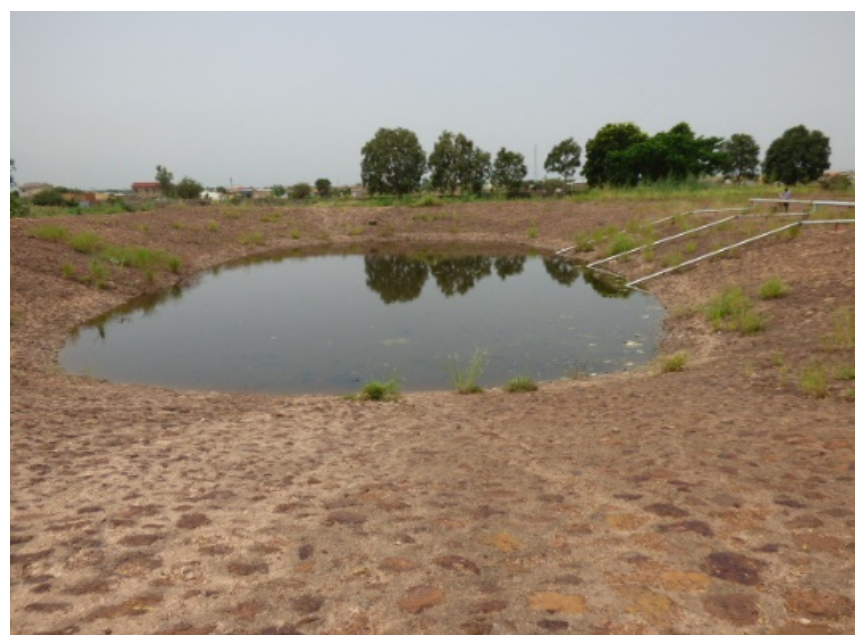

Figure 2. Household waste leachate treatment B1.

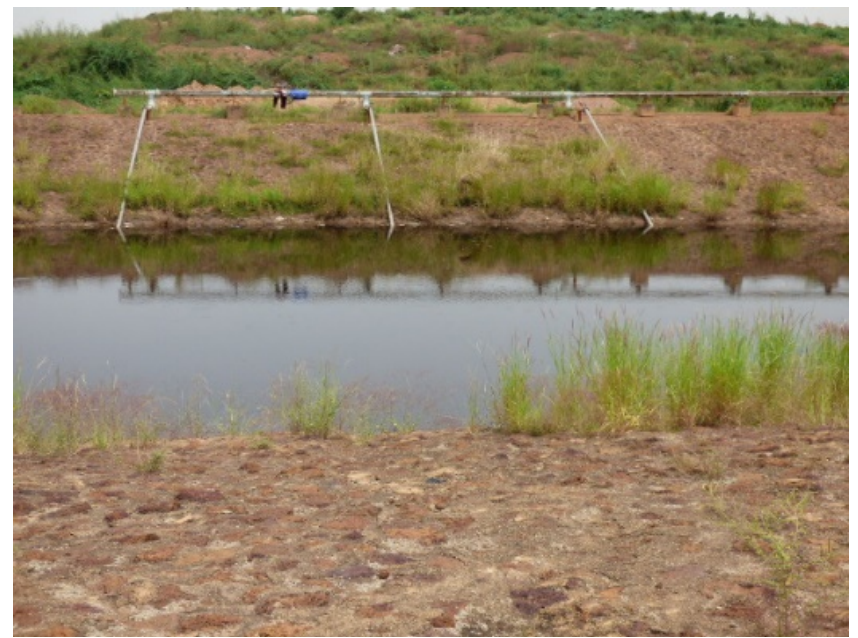

Figure 3. Household waste leachate treatment B2. 
Table 1. Characteristics of the basins (Source: Direction de la Propreté).

\begin{tabular}{cc}
\hline Two (02) tanks in series & Primary treatment then polishing \\
\hline Flow rate & $500 \mathrm{~m}^{3}$ for the rainiest month \\
Area of basins & $5747 \mathrm{~m}^{2}$ \\
Total volume of leachate to be stored & $2791 \mathrm{~m}^{3}$ \\
Total excavation volume & $15,206 \mathrm{~m}^{3}$ \\
Leachate residence time & 44 days \\
Clay-clad slope with a 1.5 mm thick geo-membrane & \\
Length & $5535 \mathrm{~m}$ \\
Width & $1845 \mathrm{~m}$ \\
Depth & $3 \mathrm{~m}$ \\
\hline
\end{tabular}

name of the person who takes the sample, the date, hour and place of sampling. Parameters such as temperature, $\mathrm{pH}$ and dissolved oxygen and the conductivity are inscribed after their measurement in-situ. The samples taken at the exit of each basin are placed in a cool box and conveyed to the laboratory where they are placed at a temperature of less than $4^{\circ} \mathrm{C}$ for the purpose of later analysis like $\mathrm{COD}, \mathrm{BOD}_{5}$, nitrates, nitrites and orthophosphates.

\subsection{Methods of Samples Analysis}

The analyses carried out on our samples are in conformity with the norms indicated in Table 2. Analyses have been carried out in ONEA laboratories, in the Environment quality analyses laboratory (LNEA) and in the laboratory of the natural substances department of IRSAT. The main analyses carried out are the physico-chemical and bacteriological analyses. The samples were taken each Monday for two months (September and October 2016) for analyses. The sample is made at more than $150 \mathrm{~cm}$ from the bank of the basin.

The samples (leachate) analysis in laboratory consists in determining the physico-chemical, biological and microbiological parameters. The following table shows the different parameters, the units as well as the analysis methods used in laboratory.

\subsection{Physico-Chemical Parameters}

1) Temperature, $\mathrm{pH}$, electrical conductivity and dissolved oxygen.

Temperature, $\mathrm{pH}$, electrical conductivity and dissolved oxygen have been recorded in situ using a WTW 3401/SET multimeter disposing of three sounds for these measurements.

The display of the temperature is coupled in. The reading is made after the display stabilization.

2) Suspended Solid (SS)

Suspended Solid (SS) constitute the whole of mineral and/or organic particles present in natural or polluted water. They correspond to the concentration of non-dissolved elements of a sample. The abundance of SS in water causes a re- 
Table 2. Analytical methods.

\begin{tabular}{ccc}
\hline Parameters & Units & Analytical methods \\
\hline $\mathrm{pH}$ & & \\
Temperature & ${ }^{\circ} \mathrm{C}$ & AFNOR 90-008 \\
Dissolved oxygen & $\mathrm{mg} / \mathrm{L}$ & \\
Conductivity & $\mu \mathrm{S} / \mathrm{cm}$ & AFNOR T 90-033 \\
Turbidity & $\mathrm{NTU}$ & AFNOR T 90 105 \\
Suspended Solid & $\mathrm{mg} / \mathrm{L}$ & HACH DR/2400 \\
COD & $\mathrm{mg} \mathrm{of} \mathrm{O}_{2} / \mathrm{L}$ & AFNOR T 90-103 \\
BOD & $\mathrm{mg} \mathrm{of} \mathrm{O}_{2} / \mathrm{L}$ & \\
& & Seeding on specific agar \\
FC & UFC/100ml & (chromocult Agar ES for coliforms) \\
& &
\end{tabular}

duction of the sunlight penetration into water and therefore a reduction of the biological production particularly because of a fall in dissolved oxygen by reduction of photosynthesis phenomena. In the purification stations, the SS can be eliminated through a simple decantation or through decantation caused with the addition of a coagulant. In the lagoon basins, these ones are eliminated through sedimentation followed by their digestion in the mudzone.

In this study, the determination of SS has been made the day of sampling, using the weighing method after filtering on GFC filter and drying at $105^{\circ} \mathrm{C}$. The concentration in SS is obtained by the following formula (1)

$$
\mathrm{SS}=\mathrm{SS}(\mathrm{mg} / \mathrm{L})=1000 * \frac{M_{1}-M_{0}}{V}
$$

With:

$M_{0}$ (g): Mass of the dry filter paper in mg before filtering

$M_{1}(\mathrm{~g})$ : Mass of the filter paper after filtering and drying at $105^{\circ} \mathrm{C} \mathrm{V}(\mathrm{mL})$ : volume of the sample filtered

3) Chemical Oxygen Demand (COD)

The Chemical Oxygen Demand (COD) expressed in $\mathrm{mg}$ of $\mathrm{O}_{2} / \mathrm{L}$ is the concentration in oxygen equivalent to the quantity of dichromate $\left(\mathrm{Cr}_{2} \mathrm{O}_{7}^{2-}\right)$ consumed by oxidation through chemical way of matters liable to rust. Oxidation was done for 2 hours at the temperature of $150^{\circ} \mathrm{C}$ and this in acid milieu, in presence of silver sulfate (catalyst) and mercuric sulfate (used to eliminate the interferences caused by chlorides ions).

The reading is made using a DR $2400 \mathrm{HACH}$ spectrophotometer. It permits to appreciate the concentration in organic and mineral matters, dissolved or in suspension in water, through the quantity of oxygen requested for their total oxidation by chemical way.

4) The 5-day Biochemical Oxygen Demand $\left(\mathrm{BOD}_{5}\right)$

The 5-day Biochemical Oxygen Demand $\left(\mathrm{BOD}_{5}\right)$ is the quantity of oxygen 
requested for the biodegradation of organic matters by biological processes. The determination of $\mathrm{BOD}_{5}$ is useful for evaluating the concentration of organic pollutants in entry and exit of a biological treatment system to appreciate the treatment yield. It is the quantity of oxygen consumed by the microorganisms present in a water sample, during the incubation for five days at $20^{\circ} \mathrm{C}$, in a thermostatic store and in darkness to ensure the degradation of the biodegradable organic matter. The incubation is carried out in darkness to prevent any oxygen production through the photosynthesis, in situation of the presence of algae or photosynthetic bacteria in the sample. The measurement of the $\mathrm{BOD}_{5}$ is carried out using an Oxytop system based on the principle of pressure difference, after the elimination of the nitrification interference by addition of $\mathrm{N}$-allylethiourea reagent.

\subsection{Microbiological Parameter}

\section{Fecal Coliforms}

The analysis of fecal coliforms starts the day of the sampling. The counting of fecal coliforms has been carried out using the filtering technique on membrane. The principle is mentioned in the French norm NF in ISO 9308-1. The essay consists in a filtering on membrane which pores have a size of $0.45 \mu \mathrm{m}$, followed by a culture in a differentiation agar-agar (Chromocult Agar ES) and then incubated at $36^{\circ} \mathrm{C}\left( \pm 2^{\circ} \mathrm{C}\right)$ during $48 \mathrm{~h}$. After confirmation, the number of formative units of colonies is expressed as follows (2).

$$
C=\frac{A * N * V s}{B * V t}
$$

With: $C$, number of colonies per $100 \mathrm{~mL}$;

$A$, number of characteristic/or controlled colonies;

$B$, number of colonies sub-cultured for control;

$N$, number of presumed colonies;

$V t$, volume of the sample or the dilution of this one, expressed in millimeter;

$V s$, volume which must be reported by the result $(100 \mathrm{~mL})$.

\section{Results and Discussions}

\subsection{Results of Physico-Chemical Analysis}

The results of leachate analysis through samplings for two months (September and October 2016) are written down in the Table 3.

When comparing the parameters average values with the waste water throwing out norms in the nature, we notice that parameters such as $\mathrm{pH}$, temperature, conductivity, nitrites $\left(\mathrm{NO}_{2}^{-}\right)$, nitrates $\left(\mathrm{NO}_{3}^{-}\right)$and ortho-phosphates $\left(\mathrm{PO}_{4}^{3-}\right)$ respect this norm fixed by Burkina Faso. As for Suspended Solids, the Chemical Oxygen Demand, the 5-day Biochemical Oxygen Demand and fecal coliforms (FC) present very high values, given the national standard. Leachate presents a low content in nitrates and ortho-phosphates which are undesirable substances and source of eutrophication.

Concerning the standard deviation, we have observed that some parameters 
Table 3. Physico-chemical characteristics of the leachate generated by the household rubbish of the WTVC.

\begin{tabular}{|c|c|c|c|c|c|c|c|c|c|}
\hline & & B & & & & & B 2 & & \\
\hline Parameters & Minimum & Maximum & Average & $\begin{array}{l}\text { Standard } \\
\text { deviation }\end{array}$ & Minimum & Maximum & Average & $\begin{array}{l}\text { Standard } \\
\text { deviation }\end{array}$ & $\begin{array}{c}\text { Wastewater discharge } \\
\text { standards }\end{array}$ \\
\hline $\mathrm{pH}$ & 8.62 & 9.23 & 8.91 & 0.23 & 9.01 & 9.51 & 9.23 & 0.19 & $6.5-9$ \\
\hline Temperature $\left({ }^{\circ} \mathrm{C}\right)$ & 27.8 & 33 & 30.82 & 1.83 & 27.7 & 32.9 & 30.62 & 1.76 & 40 \\
\hline Dissolved Oxygen $(\mathrm{mg} / \mathrm{L})$ & 6.4 & 8.64 & 7.01 & & 5.2 & 8.73 & 7.06 & & \\
\hline $\begin{array}{l}\text { Electrical Conductivity } \\
\qquad(\mu \mathrm{S} / \mathrm{cm})\end{array}$ & 510 & 625 & 557 & 42.58 & 485 & 554 & 518 & 24.56 & - \\
\hline Suspended Solid (mg/L) & 6000 & 38,000 & 14,000 & 4647 & 9000 & 19,000 & 13,714 & 3794 & 150 \\
\hline $\mathrm{NH}_{4}(\mathrm{mg} / \mathrm{L})$ & 0 & 0 & 0 & 0 & 0 & 0 & 0 & 0 & \\
\hline $\mathrm{NO}_{3}^{-} \quad(\mathrm{mg} / \mathrm{L})$ & 12 & 20 & 15.75 & & 0.7 & 0.95 & 0.82 & 0.00 & 50 \\
\hline $\mathrm{NO}_{2}^{-} \quad(\mathrm{mg} / \mathrm{L})$ & 0 & 0.155 & 0.047 & 0.06 & 0 & 0.041 & 0.016 & 0.02 & 1 \\
\hline $\begin{array}{l}\text { OrthoPhosphate }\left(\mathrm{PO}_{4}^{3-}\right) \\
(\mathrm{mg} / \mathrm{L})\end{array}$ & 6.8 & 21.5 & 10.38 & 4.81 & 3.9 & 17.4 & 11.48 & 6.18 & \\
\hline $\mathrm{COD}\left(\mathrm{mg} \mathrm{O}_{2} / \mathrm{L}\right)$ & 240 & 660 & 440 & 59.90 & 260 & 480 & 364 & 65.40 & 150 \\
\hline $\mathrm{BOD}_{5}\left(\mathrm{mg} \mathrm{O}_{2} / \mathrm{L}\right)$ & 16.9 & 390 & 143 & 3.96 & 28.7 & 210 & 99.53 & 22.06 & 40 \\
\hline C F UFC/100mL & 200 & 10,000 & 2964 & 2002 & 700 & 12,800 & 4674 & 5921 & 2000 \\
\hline
\end{tabular}

like $\mathrm{pH}$ and temperature have values which are pooled about the average, whereas other parameters like the SS, fecal coliforms have very dispersed values about the average.

The yields of the pollution elimination are not appreciable for SS, COD, and $\mathrm{BOD}_{5}$, with respective yields of $2.04 \%, 15.57 \%$ and $30.46 \%$, there was release of orthophosphate and fecal coliforms with negative yields.

\subsection{Discussion}

\section{1) Temperature}

The average temperatures registered during the period of the study are respectively $30.82^{\circ} \mathrm{C}$ and $30.62^{\circ} \mathrm{C}$ for basin 1 and basin 2 . These values comply with the standard fixed in Burkina Faso, since these ones are included between 18 and $40^{\circ} \mathrm{C}$. Some authors have recorded an average temperature of $29.8^{\circ} \mathrm{C}$ [3], close to the average of this study results. The temperature depends on climate conditions [4]. To evaluate the characteristics of a treatment, temperature is an important parameter as far as the kinetic of bacteria and biological activity is dependent on climatic conditions. Since the temperature varies according to seasons, indirectly the basins purification performance varies according to the period of the year. In that way, we observe that during the dry season, the biological activity is more important than during the rainy season. It can be noted that in the study area, the maximum temperature can reach $45^{\circ} \mathrm{C}$ in dry season [5], with the dry wind. These conditions favor a strong evapotranspiration since Koné reports 207.8 $\mathrm{mm} / \mathrm{month}$ as value of the Penman potential evapo- transpiration in the city of Ouagadougou [6].

2) Hydrogen potential: $\mathrm{pH}$ 


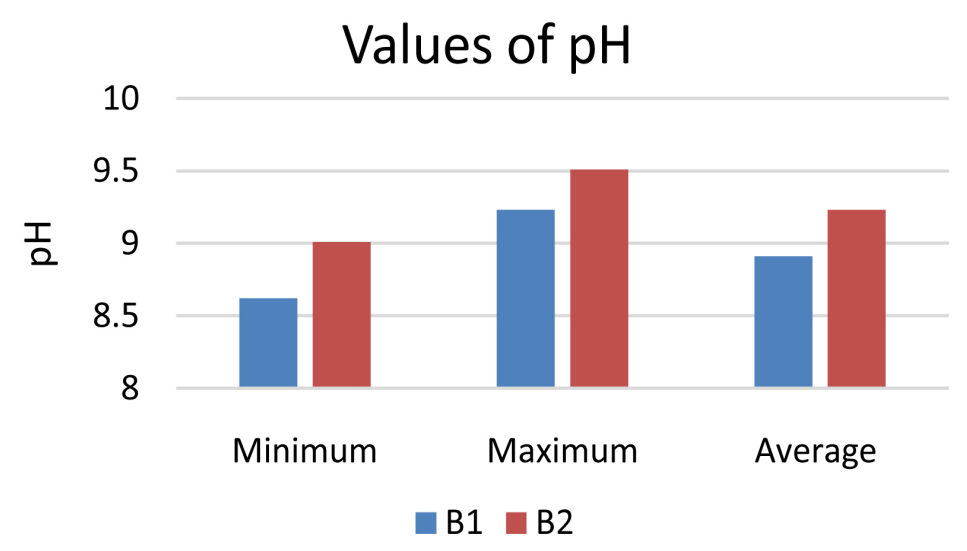

Figure 4. The values of $\mathrm{pH}$ in the basins.

Figure 4 shows the mean $\mathrm{pH}$ values of the two basins. Indeed, the averages respectively 8.91 and 9.23 in basin 1 (B1) and basin 2 (B2). Minimal and maximalpH obtained are respectively 8.62 up to 9.23 for B1 and 9.01 up to 9.51 for B2. This is acceptable considering the national regulation included between 6.5 and 9. The $\mathrm{pH}$ recorded in basin 2 during this study is higher than the $\mathrm{pH}$ recorded in basin 1 as shown in Figure 4 due to development of algae and good oxygenation condition [4]. Some authors have recorded an average $\mathrm{pH}$ of 8.44 for a value widely below those obtained in the framework of this study [7]. It is important to note that $\mathrm{pH}$ is function of the effluents ageing [8]. The $\mathrm{pH}$ is a determinant factor for the survival of microorganisms in the purifying stations. A too much acid or too basic $\mathrm{pH}$ would cause the death of these ones and would compromise the treatment efficiency. Low $\mathrm{pH}$ (acid milieu) notably increases the risk of metals presence under a more toxic ionic form, while the basic $\mathrm{pH}$ increases the ammoniac concentrations which are toxic for the ecosystem. The $\mathrm{pH}$ recorded in the two basins remain within the limit of values allowed by the national regulation.

3) Electrical Conductivity

The average of electrical conductivities of the lagoons B1 and B2 are respectively $557 \mu \mathrm{S} / \mathrm{cm}$ for B1 and $518 \mu \mathrm{S} / \mathrm{cm}$ for B2 as shown in Figure 5. Minimal and maximal values obtained are respectively $510 \mu \mathrm{S} / \mathrm{cm}$ and $625 \mu \mathrm{S} / \mathrm{cm}$ for B1 and $485 \mu \mathrm{S} / \mathrm{cm}$ up to $554 \mu \mathrm{S} / \mathrm{cm}$ for B2. Lagoon 1 present a higher electrical conductivity with regard to those of lagoon 2. Some authors have observed a more important conductivity, like El Kharmouz who mention an average electrical conductivity value of $170,000 \mu \mathrm{S} / \mathrm{cm}$ about the leachates of the public dumping of the city of Oujda in Morocco [1]. The electrical conductivity reduction on second lagoon could be explained by the retaining of mineral salts in the mud decanted in the bottom of the lagoon on the one hand, and by the algae consumption on the other hand. Though, a yield of $7.03 \%$ remains low. This is essentially due to the very important evaporation in the study zone. Nevertheless, on examining the values recorded by other authors, we can assert that leachate derived from household rubbish of the center do not present a high 


\section{Electrical conductivity}

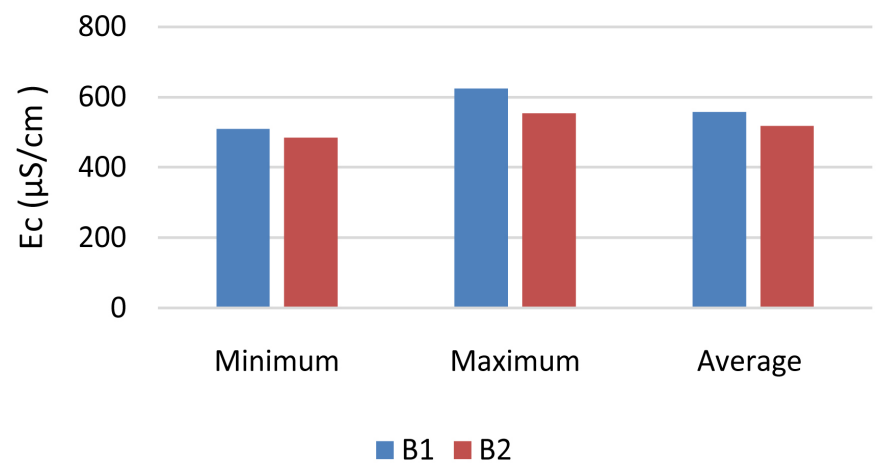

Figure 5. Electrical conductivity values in the basins.

salinety [1] [9]. In general, aquatic species do not support important variations in dissolved salts which can be observed for instance in case of waste water discharge. Actually, an excessive increase of the surface water electrical conductivity generates modifications of the bacterial ecosystem and also has an influence on the survival of the aquatic fauna and flora. A too important salinity of the thrown-out waters could cause the soil clogging and negatively impact the growing of some speculations in agriculture. Concerning the electrical conductivity, the throwing out of leachate treated is compatible with the requirements of the receiving milieu.

4) Dissolved oxygen

The evolution of dissolved oxygen in the lagoons indicates that minimal and maximal values of basin 1 are $6.4 \mathrm{mg} / \mathrm{L}$ and $8.68 \mathrm{mg} / \mathrm{L}$; those of basin 2 are 5.2 $\mathrm{mg} / \mathrm{L}$ and $8.73 \mathrm{mg} / \mathrm{L}$ with an average of $7.01 \mathrm{mg} / \mathrm{L}$ for B1 and $7.07 \mathrm{mg} / \mathrm{L}$ for B2. This could confirm that the basins are well-aerated due to the shallow depth of water in the basins. Some authors have recorded a low average value in dissolved oxygenlike Toklo and collaborator who indicated an average of $1.07 \mathrm{mg} / \mathrm{L}$, which is below the average values recorded during this study [10]. The content of oxygen is a very important parameter for the survival of microorganisms. The lack of dissolved oxygen in the waste waters induces a process of anaerobia degradation with a smell emanation as consequence. Purifying waste water, means to reduce considerably organic and microbiological pollution in order to increase its concentration in dissolved oxygen. Therefore, we can say that effluents derived from the leachate treatment are oxygenated in a quite important way to ensure the survival of the purifier microorganisms.

5) Suspended Solids (SS)

The average concentration of Suspended Solids (SS) measured in the leachate is $14,000 \mathrm{mg} / \mathrm{L}$ for basin 1 and $13,714 \mathrm{mg} / \mathrm{L}$ for basin 2 as indicated in Figure 6 below. Minimal and maximal values are $6000 \mathrm{mg} / \mathrm{L}$ and 38,000 mg/L for B1 and $9000 \mathrm{mg} / \mathrm{L}$ up to $19,000 \mathrm{mg} / \mathrm{L}$ for B2. Basin 1 has presented the highest content in Suspended Solids compared with basin 2. In any case the values recorded in the two basins remain far beyond the norm admitted by the national regulation 


\section{Suspended Solids}

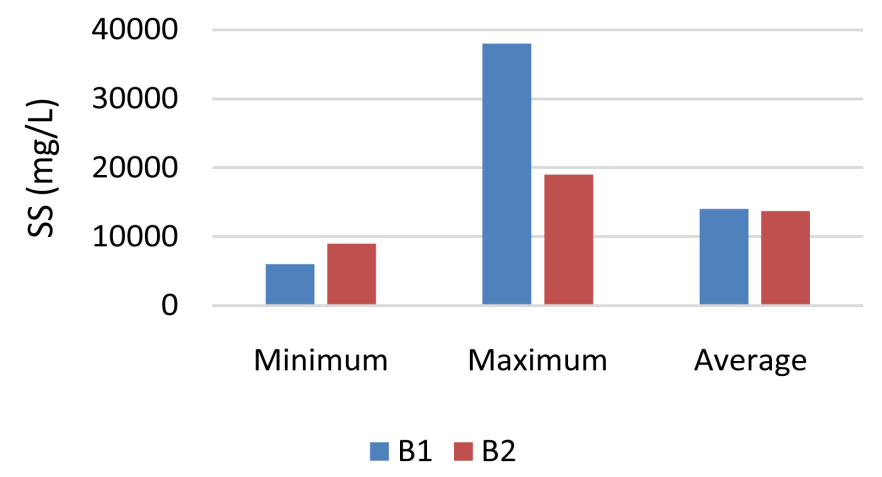

Figure 6. The values of suspended solids in the basins.

as regards the throwing of waste waters in the nature. In fact, the national norm fixes the limit at $150 \mathrm{mg} / \mathrm{L}$ for a lagoon process. This could be explained by the worse conditions of decantation in the basins, considering the less important volumes of leachate and given the works size.

In other contexts, some authors have recorded average less important contents in Suspended Solids. It is the case of leachates from the landfill in the city Essaouira in Marocco [7].

The determination of content in Suspended Solids is important in the characterization of effluents and the choice of technology to be implemented, since it permits to assess the breakdown of pollution between the dissolved phase and the particle phase. On examining the contents which are too important in Suspended Solids at the exit of the system, it is obvious from this, that the treatment is less efficient on the Suspended Solidsreduction, so that effluents derived from the treatment by the two basins in series require an additional quantity of water regarding the size of basins and it needs an additional treatment to make them in accordance with the throwing norms in the natural milieu.

6) Nitrogen

Ammonium ( $\mathrm{NH}_{4}^{+}$)

The degradation of organic nitrogen in ammonium is an integral part of the nitrogen cycle in the production of nutriments. Ammonium nitrogen is toxic for aquatic life. In natural water, ammonium nitrogen comes mainly from the leachingof farming wateras well as waste water from the cities and industries in an anaerobia milieu. In the framework of this study ammonium pollution is nearly absent in the two basins. This confirms the basins fair oxygenation which ensures an aerobic treatment. On the contrary, some authors have recorded important average values in ammonium [3]. The more or less high presencein ammonium nitrogen could be connected to the origin of waste but also to an anaerobic process within the treatment system.

Nitrates $\left(\mathrm{NO}_{3}^{-}\right)$

Nitrates constitute the final stage of organic nitrogen oxidation in water and 
representthe nitrogen form at the highest oxidation degree. Nitrifying bacteria (nitrobacteria) transforms nitrites into nitrates. This reaction accompanied with oxygen consumption. High contents in nitrates causean alga proliferation which contributes to the eutrophication (suffocation of aquatic life) of the milieu [11]. Nitrates permit to bring nitrogen to the plant and when they are excessive, they can have a negative impact on crops. Indeed, an excess of nitrates involvesmaturation delays and a modification of the product quality. In the framework of this study, respective average concentrations in nitrate obtained are $15.75 \mathrm{mg}$ of N/L for B1 and $0.82 \mathrm{mg}$ of N/L for B2. That corresponds to $94.78 \%$ of yield. It means good condition of nitrification due to presence of oxygen in the basin 1 following by algae consumption in basin 2 .

Nitrite $\left(\mathrm{NO}_{2}^{-}\right)$

About nitrite, the average contents recorded are $0.05 \mathrm{mg} / \mathrm{L}$ for $\mathrm{B} 1$ and 0.02 $\mathrm{mg} / \mathrm{L}$ for B2. On looking at the national regulation which impose a limit value inferior to $1 \mathrm{mg} / \mathrm{L}$, it is evident from this study that these waters are without a particular risk connected to the presence of nitrite. It is important to note that nitrites could cause the methemoglobinemia, resulting from an oxidation of the hemoglobin. The formation of methemoglobin in great quantity reduces the cells oxygenationwhich can be express through a cyanosis, blue-tinged coloration of the skin and mucous membranes and causes asphyxiation and death [11]. Babies of less than three months are the most exposed to this risk owing to the low acidity of their stomach, their tendency to develop gastro-intestinal infections and their low capacity to regenerate hemoglobin from the methemoglobin. Besides, owing to the interactions between nitrites, amides and the amines likely to form carcinogenic nitrogenous compounds, suspicions of carcinogenicity weigh on nitrate.

7) Ortho-phosphates

The average concentrations in Ortho-phosphates are $10.38 \mathrm{mg} / \mathrm{L}$ for $\mathrm{B} 1$ and $11.48 \mathrm{mg} / \mathrm{L}$ for $\mathrm{B} 2$. The national regulationdoes not require limit values on this parameter, but we can observe that the concentration increases in B2. This suggests a re-dropping of ortho-phosphate ionsfrom the muds accumulated within this basin or an external contamination owing to the entropic activities around the basins. Nevertheless, the contents in ortho-phosphates remain low, even if maximal contents of $21.5 \mathrm{mg} / \mathrm{L}$ have been achieved, and this on examining more important values reported by other authors. In fact, KOUASSI and collaboratorrevealed the average value of $128 \mathrm{mg} / \mathrm{L}$ [3]. The contents variability is function of the waste characteristics. Though, it is important to note that phosphorus associated with nitrogen constitutes the cause of eutrophication phenomenon expressed by a high production of biomass [11]. Besides, this mixture may cause the degradation of water organoleptic properties (smell, color, aspect) and favor the appearance of toxic or pathogen micro-organisms. Cyanobacteria generated by the combined effect of ortho-phosphates and nitrates, may become dangerous for fauna and flora through the release of 
cyanotoxins which are sometimes mortal for animals and dangerous for human being.

8) Chemical oxygen demand (COD)

The Chemical oxygen demand (COD) is an important parameter permitting to characterize the global pollution of water. The average values of COD recordedare $440 \mathrm{mg} \mathrm{O}_{2} / \mathrm{L}$ for $\mathrm{B} 1$ and $364 \mathrm{mg} \mathrm{O}_{2} / \mathrm{L}$ for B2 (Figure 7). These values are proved to be superior to the limit value authorized by the national norm which is $150 \mathrm{mg} / \mathrm{L}$ for throwing out derived from purifying process through lagoon, even if some authors have recorded more important average contents. Indeed, other studies mentioned an average concentration in COD of 10,361 mg/L [7] or an average value of $72,000 \mathrm{mg} / \mathrm{L}$ [9]. These values are far beyond our results, and could be explained by the importance of organic charges admitted in the site and by the basins oxygenation conditions, compared with this study. Anyway, the treatment by the two basins remains less efficient on the elimination of COD, since the elimination yield is only $17.20 \%$. On looking at this weak performance of the works, the throwing should only be authorized after an additional treatment.

9) The 5-day Biochemical Oxygen Demand $\left(\mathrm{BOD}_{5}\right)$

The ratio $\mathrm{BOD}_{5} / \mathrm{COD}$ values are 0.52 and 0.43 respectively for basin 1 and basin 2 indicate that the leachates are still biodegradable and young [7] [13]. Though, Figure 7 which presents the behavior of the two basins as for the $\mathrm{BOD}_{5}$, reduction shows low performances. Actually, the average values of $\mathrm{BOD}_{5}$ which are $143 \mathrm{mg} \mathrm{O}_{2} / \mathrm{L}$ for $\mathrm{B} 1$ and $99 \mathrm{mg} \mathrm{O}_{2} / \mathrm{L}$ are proved to be superior to the norms fixed by the regulation in Burkina Faso. These norms impose a maximal content of $40 \mathrm{mg} / \mathrm{L}$. Besides, the yield corresponding to $30.46 \%$ is proved to be low. These values recorded give evidence for a high presence of organic matters undigested by bacteria during the treatment. This state of fact could be justified by the lack of bacteria in the system and by the initial charge which is very high. The Biochemical oxygen demand $\left(\mathrm{BOD}_{5}\right)$ represents the quantity of oxygen used

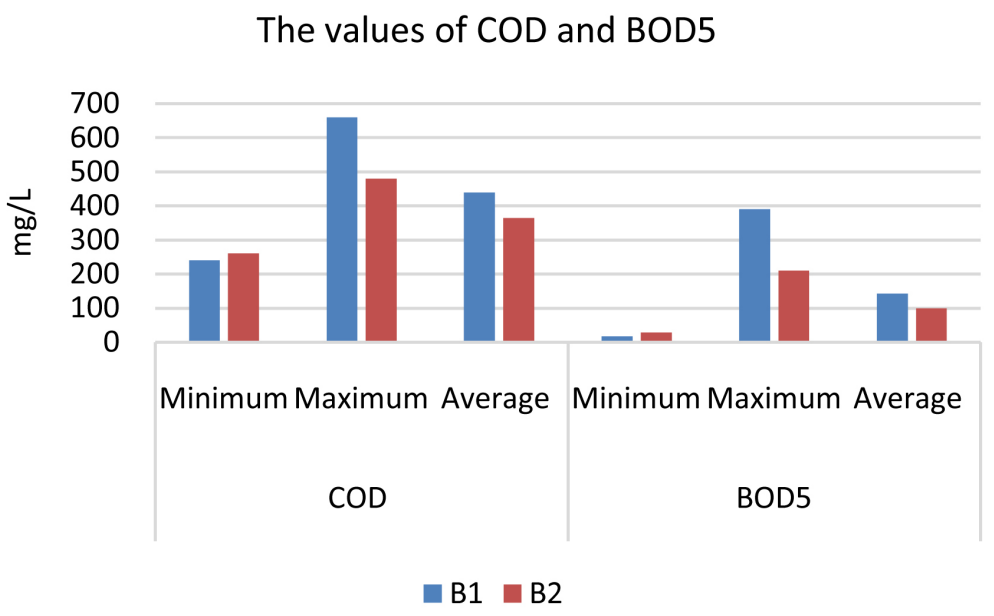

Figure 7. $\mathrm{COD}$ and $\mathrm{BOD}_{5}$ values in the basins. 
by the bacteria to partially or totally oxidize biodegradable matters in water and which constitute their carbonic source (fat, carbon hydrates etc.). This oxygen sampling is carried out to the detriment of other living organisms in aquatic milieu. Therefore, since the basins are well oxygenated, the yield should be superior to $30.46 \%$ recorded. It is certain that aerobic conditions are not set up considering the concentrations in dissolved oxygen of the basins which are respectively 7.01 and $7.06 \mathrm{mg} / \mathrm{L}$. This is corroborated by the lack of ammonium during the treatment. Very likely, the stay time in the basin B1 is too short to ensure a good reduction of the biodegradable organic pollution. Yet, other studies have given more important average contents in $\mathrm{BOD}_{5}$ [3] [12]. In any case, the results remain unsatisfactory, considering the quantity of residual biodegradable organic matters.

\subsection{The Presence of Microbiological Pollution}

The bacteriological analysis was related to the determination of concentrations in fecal coliforms within the leachate derived from household rubbish (Figure 8). Fecal coliforms are a group of bacteria being a part of total coliforms. Their presence in the treatment basins indicates that these last ones could also contain pathogen microorganisms. In fact, fecal coliforms constitute a group of bacteria of which the detection in the environment generally gives evidence for fecal pollution. The average content of fecal coliforms is $3700 \mathrm{UFC} / 100 \mathrm{~mL}$ for B1 and $5825 \mathrm{UFC} / 100 \mathrm{~mL}$ for $\mathrm{B} 2$. These values are not acceptable considering the limit value admitted by the national standard which imposes $2000 \mathrm{UFC} / 100 \mathrm{~mL}$. The extreme values are $200 \mathrm{UFC} / 100 \mathrm{~mL}$ and $10,000 \mathrm{UFC} / 100 \mathrm{~mL}$ for $\mathrm{B} 1$ and 700 $\mathrm{UFC} / 100 \mathrm{~mL}$ and $12,800 \mathrm{UFC} / 100 \mathrm{~mL}$ for B2. Since fecal coliforms derive from fecal matters their presence could be explained by the presence of animal feces and excreta contained in the rubbish; but it also could be favored by defecationin the open air near the basins. As far as the increase of the concentrations in basin B2 is concerned, this could be related to a phenomenon of resetting in suspension of decanted muds through an important arrival of water. This is particularly plausible since we have noticed an increase of ortho-phosphates concentrations in the same time as pointed out above. The treatment by the two successive

\section{The values of fecal coliforms}

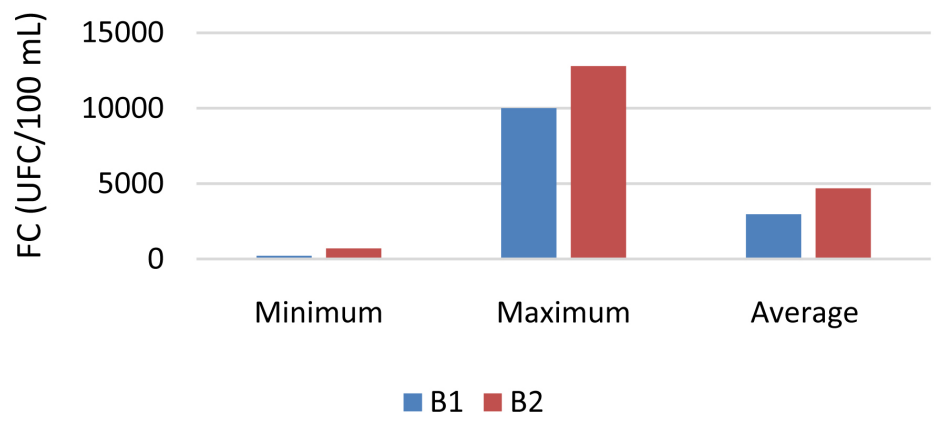

Figure 8. Fecal coliforms values in the basins. 
basins gives less satisfactory results with values exceeding the admitted standards and an increase of the contents in basin B2. Other researcher cited an average value of $5 \times 10^{7} \mathrm{UFC} / 100 \mathrm{~mL}$ concerning household waste leachate from Kenitra in Morocco [13]. They generally noted as we did that microbiological quality of leachates is not satisfactory.

\section{Conclusion}

The evaluation of the purifying performance related to the treatment basins of the leachate derived from household rubbish of the Waste Treatment and Valorization Center of Ouagadougou has permitted to point up the effluents characteristics. It results from the physico-chemical analysis that if nitrates and nitrites are well-eliminated, these leachates are subject toless satisfactory reductions on the important parameters such as COD with only yields of about $17.20 \%$. This undeniable fact could be related to a bad measurement for too short stay times regarding the high charge of pollution admitted in the system. Concerning the bacteriological pollution, we can note a recontamination of basins by the fecal coliforms, considering the anthropogenic activities near the site. On the whole, in the light of this study, to get better performances of the system, an additional treatment is proved to be necessary through the adding of new basins in series to those already existing, in order to preserve environment and human being health.

\section{Acknowledgements}

We are thankful to Direction of the cleanliness of the commune of Ouagadougou for providing us some information we have mentioned in our paper.

\section{References}

[1] El Kharmouz, M., Sbaa, M., Chafi, A. and Saadi, S. (2013) The Study of the Impact of Leachate from the Former Landfill of the City of Oujda (Eastern Morocco) on the Physicochemical Quality of Groundwater and Surface Water. Larhyss Journal, 16, 105-119.

[2] Idani, B.D. (2010) Geographic Information System and Waste Management in Ouagadougou: Case of Sector 30 of Bogodogo District. Mémoire de Master, Université de Ouagadougou, $100 \mathrm{p}$.

[3] Kouassi, A.E., Ahoussi, K.E., Koffi, Y.B., Kouame, I.K., Soro, N. and Biemi, J. (2014) Physico-Chemical Characterization of Leachate from a West African Landfill: Case of the Akouedo Landfill (Abidjan-Cote d'Ivoire). Larhyss Journal, 19, 36-74.

[4] Khattabi, H., Aleya, L. and Mania, J. (2002) Natural Lagooning of Landfill Leachate. Revue des sciences de l'eau, 151, 411-419. https://doi.org/10.7202/705462ar

[5] Lalanne, F. (2012) Study of the Water Quality along the Supply Chain at the Level of Consumers in 10 Villages in the Province of Ganzourgou. Fondation 2iE, $71 \mathrm{p}$.

[6] Koné, M., Zongo, I., Bonou, L., Koulidiati, J., Joly, P., Bouvet, Y. and Sodre, S. (2011) Urban Wastewater Treatment by Vertical Flow Constructed Wetland in Sudano-Sahelian Climate. International Journal of Biological and Chemical Sciences, 5, 217-231. 
[7] Chiguer, H., El Khayyat, F., El Rhaouat, O., Rifki, R., Bensaid, A. and El Kharrim, K. (2016) Assessment of Pollutant Loads of Leachates from the Controlled Landfill of the City of Essaouira (Morocco). International Journal of Innovation and Applied Studies, 14, 863-874.http://www.ijias.issr-journals.org/

[8] Grisey, E. (2013) Impact of Waste Evolution of a Non-Hazardous Waste Storage Facility on the Environment. Ph.D. Thesis, University of Franche-Comte, 1-214.

[9] Jirou, Y., Harrouni, M.C., Belattar, M., Fatmi, M. and Daoud, S. (2014) Treatment of Leachate from the Grand Agadir Controlled Landfill by Intensive Aeration. Revue Marocaine des Sciences Agronomiques et Vétérinaires, 2, 59-69.

[10] Toklo, R.M., Josse, R.G., Topanou, N., Togbe, A.F.C., Dossou-Yovo, P. and Coulomb, B. (2015) Physico-Chemical Characterization of Landfill Leachate: Case of the Ouesse-Ouidah Sanitary Landfill (South Benin). International Journal of Innovation and Applied Studies, 13, 921-928.

[11] WHO (2006) WHO Guidelines for the Safe Use of Wastewater, Excreta and Greywater. Volume II Use of Wastewater Use in Agriculture. 222.

[12] Idlahcen, A., Souabi, S., Taleb, A., Zahidi, K. and Bouezmarni, M. (2014) Evaluation of Pollution Generated by Landfill Leachate Public of the City of Mohammedia and Its Impact on the Groundwater Quality. Scientific Study \& Research Chemistry \& Chemical Engineering, Biotechnology, Food Industry, 15, 35-50.

[13] Abed, H., Esamil, A., Barrahi, M., Chahboun, N., Khadmaoui, A. and Ouhssine, M. (2014) Analytical Evaluation of the Microbiological Water Quality of Landfill Leachate Kenitra. International Journal of Innovation and Applied Studies, 7, 12251231. http://www.ijias.issr-journals.org/ 